\title{
CARBON CONTENTS AND MODELLING OF TOTAL ORGANIC CARBON FOR Pinus taeda L. FROM NATURAL REGENERATION ${ }^{1}$
}

\author{
Rafael Cubas ${ }^{2 *}$, Emanuel Arnoni Costa² and Viviane Zaniz ${ }^{3}$
}

\footnotetext{
${ }^{1}$ Received on 22.05.2014 accepted for publication on 22.06.2016.

${ }^{2}$ Universidade Federal de Santa Maria, Programa de Pós-Graduação em Engenharia Florestal, Santa Maria, RS - Brasil. E-mail: <florestal.rafael@gmail.com> and <emanuelarnonicost@hotmail.com>.

${ }^{3}$ Universidade do Contestado, Graduanda em Engenharia Florestal, Canoinhas, Santa Catarina - Brasil. E-mail: <vivikaflorestal@hotmail.com>.

*Corresponding author.
}

\begin{abstract}
This study aimed to quantify total carbon and its compartments: roots, stems, branches, and aciculas, in order to select an estimated equation of the total organic carbon for Pinus taeda L. settled from natural regeneration in the forest understory of a planted forest in the municipality of Três Barras, SC. Data have been collected from a random selection of 96 individuals with diameter at 0.3 meters above ground level, varying from 2.5 to $19 \mathrm{~cm}$. The selected individuals had their dimensional variables (dendrometric and morphometric variables) measured being subsequently felled and their compartments separated, weighed and samples were collected and taken to analysis of carbon contents. Eight traditional models were tested, six arithmetic and two logarithmic, as well as a model developed by the Stepwise process, being total organic carbon the dependent variable, and dimensional variables the independent variables. The total organic carbon found was $46.7 \%$ on average, and Tukey-Kramer test indicated significant differences of carbon contents amongst compartments. In comparison with traditional equations tested, the equation adjusted by Stepwise seemed more accurate, with good fit $\left(\mathrm{R}^{2} \mathrm{aj} .=0.931\right)$ and precision $(\mathrm{Syx} \%=18.5)$.
\end{abstract}

Keywords: Dry weight; Forest population; Carbon sequestration.

\section{TEORES DE CARBONO E MODELAGEM DO CARBONO ORGÂNICO TOTAL PARA Pinus taeda L. PROVENIENTE DE REGENERAÇÃO NATURAL}

\begin{abstract}
RESUMO - Os objetivos deste trabalho foram quantificar o carbono total e dos compartimentos: raizes, fustes, galhos e acículas, visando selecionar uma equação estimativa do carbono orgânico total para Pinus taeda L. que se estabeleceram a partir de regeneração natural no sub-bosque de uma floresta plantada, localizada no município de Três Barras, SC. Os dados são provenientes da seleção aleatória de 96 indivíduos com diâmetro à 0,3 metros do nível do solo, variando de 2,5 a $19 \mathrm{~cm}$. Os indivíduos selecionados tiveram suas variáveis dimensionais (variáveis dendrométricas e morfométricas) medidas e, em seguida, foram abatidos e seus compartimentos separados, pesados e amostras retiradas e conduzidas para análise do teor de carbono. Foram testados 8 modelos tradicionais, sendo 6 aritméticos e 2 logaritmicos e também um modelo desenvolvido pelo processo Stepwise, tendo o carbono orgânico total como variável dependente e as variáveis dimensionais, como variáveis independentes. O teor de carbono total encontrado, em média, foi de 46, 7\% e o teste de Tukey e Cramer indicou diferenças significativas na quantidade de carbono entre os compartimentos. Em comparação com as equações tradicionais testadas, a equação ajustada por Stepwise mostrou-se mais acurada, com bom ajuste $\left(R^{2} a j .=0,931\right)$ e precisão $($ Syx\% $=18,5)$.
\end{abstract}

Palavras-chave: Peso seco; Povoamento florestal; Sequestro de carbono. 


\section{INTRODUCTION}

The concern with emission of air pollutants and measures for their mitigation has led to the development of an international market of environmentally-friendly products (ILYAS, 2013). In light of this, the carbon market is in full expansion, and several countries are approving projects to sell this type of service (BALBINOT, et al. 2008).

Forests play a specific and important role in the global cycle of carbon, absorbing carbon dioxide during photosynthesis and storing it above and below ground level (ILYAS, 2013). Although small carbon stocks occur in forests when compared with other compartments (atmosphere, soil, fossil fuels, and oceans), they are easily manageable for purposes of carbon sequestration (SANQUETTA et al., 2002). Therefore, forests have received more attention from researchers. In Brazil, studies have been developed in different forest types, among which planted forests (BALBINOT, et al., 2008; MELLO et al., 2010; WATZLAWICK et al., 2013); natural forests (RIBEIRO et al., 2009; WATZLAWICK et al., 2011; AMARO et al., 2013; TORRES et al., 2013); and native Bracatinga forests (SOUZA et al., 2013). There are no specific studies, however, for small-sized trees from natural regeneration in the understory of planted forests.

To convert the amount of dry biomass into carbon, a conversion factor of 0,5 (FONSECA et al., 2011a) is commonly used. Nevertheless, carbon contents in wood usually vary from 47 to $53 \%$ due to lignin variation and levels of extractives (RAGLAND; AERTS, 1991).

Methods for carbon quantification are laborious, time-consuming and very onerous, and may be achieved through direct and indirect methods (WATZLAWICK et al., 2006). According to the authors, trees are felled and their components separated and weighed with the direct method, whereas for the indirect method, allometric equations or satellite images are used to perform estimations.

Some authors have developed allometric equations for carbon estimations of Pinus spp trees (RITSON; SOCHACKI, 2003; SOCHA; WEZYK, 2007; CORREIA et al., 2010). However, in some locations where there are these allometric models, they are not always applicable for the same species in case it is settled in another environment (FELDPAUSCH et al., 2011). This is due to the fact that tree growth is affected by local characteristics (MAKUNGWA et al., 2013), what may result in expressive systematic errors in carbon estimation.

In light of this, this study aimed to quantify total carbon and its compartments: roots, stems, branches, and aciculas, in order to select an estimation equation of total organic carbon for Pinus taeda L. trees from natural regeneration in the understory of a planted forest in Três Barras, SC.

\section{MATERIALS E METHODS}

\subsection{Study area}

The study was performed in the Três Barras National Forest, in the municipality of Três Barras, Santa Catarina, Brazil $\left(26^{\circ} 12^{\prime} \mathrm{S}\right.$ and $\left.50^{\circ} 18^{\prime} \mathrm{W}\right)$.

According to Köppen, the climate in the area is $\mathrm{Cfb}$, temperate, constantly humid, without dry season, and with cool summer. Average annual precipitation is $1.588,0 \mathrm{~mm}$. The lowest average monthly temperature is $11.7^{\circ} \mathrm{C}$ in July, and the highest is $21.3^{\circ} \mathrm{C}$ in January. The relief of the area is flat, altitude is $730 \mathrm{~m}$, and there is frequent occurrence of frosts.

\subsection{Data collection}

A total of ninety-six individuals was randomly selected in a planted forest of Pinus taeda. The selected individuals were small-sized trees settled from natural regeneration under the planted forest.

Each individual had the following dendrometric variables measured: $\left(\mathrm{d}_{0,3}\right)$ diameter at $0.3 \mathrm{~m}$ above ground level, (h) total height, (mip) morphological inversion point corresponding to the first living branch (WATZLAWICK et al., 2012), and (cl) crown length (WINK et al., 2012). It must be highlighted that diameter at $0.3 \mathrm{~m}$ above ground level was considered due to the presence of individuals whose height was lower than $1.30 \mathrm{~m}$.

To determine biomass, each tree was divided into the following compartments: aciculas, branches, stems, and roots. Each compartment was separately measured in the field in digital scales with precision of $0.1 \mathrm{~g}$, in order to quantify humidity percentage.

For dry biomass, aciculas were sampled at the top, middle, and bottom of the crown. This same procedure was adopted for branches by collecting samples with bark in the extremity, middle, and bottom of branches. 
To analyse stems, discs were removed from the bottom, middle, and upper crown of trees. Following the weighing of biomass above ground level, root biomass of trees was quantified by excavating and removing roots, as well as weighing the material. After the weighing of the several compartments, materials were accommodated in plastic bags, taken to the laboratory and dried in airflow and air renovation kiln at $75^{\circ} \mathrm{C}$ until reaching constant weight (WATZLAWICK; CALDEIRA, 2004). Percentage of biomass contents of samples of each component were calculated based on the relationship: dry matter contents $=($ dry weight/green weight $) * 100$ (URBANO et al., 2008).

\subsection{Quantification of carbon contents}

To quantify carbon, it was necessary to perform the fractioning of samples in small parts (sawing), the aciculas were grinded in a Willye mill, stems were grinded in sandpaper, and branches and roots were grinded in a grain grinder. It is important to note that the mill and the grinder were cleaned before use and after fractioning of compartments to avoid inserting other residues into the fractioned samples.

Organic carbon analyses were conducted according to the methodology proposed by Tedesco et al. (1995), and performed in the Laboratório de Ecologia Florestal at Universidade Federal de Santa Maria (UFSM), Rio Grande do Sul, Brazil.

Database (dependent variable) of the regression models tested was developed from results obtained in the analyses of organic carbon, as described in the previous paragraph. In this sense, carbon contents (\%) found in dry biomass of each component were used as a conversion factor. Thus, each sampled individual had the carbon weight calculated for each compartment of interest. The sum of carbon weight of all compartments, for each selected tree separately, refers to the total carbon weight found.

\subsection{Equations for estimation of total carbon weight}

Six arithmetic models and two logarithmic models were tested (SEGURA; ANDRADE, 2008), and an equation was developed by Stepwise modelling for estimation of total carbon weight (Table 1).

Diameter at $0,3 \mathrm{~m}$ above ground level $\left(\mathrm{d}_{0,3}\right)$ and total height $(\mathrm{h})$ were tested as independent variables in allometric equations, once they are easily accessible and applicable in the field. For regression modelling, the Stepwise procedure tested the variables previously described plus morphological inversion point (mip) and crown length (cl) as well as their modifications and interactions in simple, quadratic, cuboidal, inverse, and logarithmic forms.

\subsection{Statistical analysis}

In order to verify whether there was statistical difference between mean values of carbon contents in the assessed compartments, Tukey-Kramer test was used at a significance level $\alpha=5 \%$.

The selection of the best model was based on adjusted coefficient of determination ( $R^{2} a j$.), standard error for percentage estimation (Syx\%), graphic analysis

Table 1 - Equations tested to estimate total carbon weight in natural regeneration of Pinus taeda. Tabela 1 -Equações testadas para a estimativa do peso do carbono total em regeneração natural de Pinus taeda.

\begin{tabular}{ccc}
\hline Equation & Author & Model \\
\hline Aritmethic & & \\
\hline 1 & Berkhout & $\mathrm{PCT}=\beta_{0}+\beta_{1} * \mathrm{~d}_{0,3}+\varepsilon$ \\
2 & Kopezky & $\mathrm{PCT}=\beta_{0}+\beta_{1} * \mathrm{~d}_{0,3}{ }^{2}+\varepsilon$ \\
3 & Hohenadl - Krenn & $\mathrm{PCT}=\beta_{0}+\beta_{1} * \mathrm{~d}_{0,3}++\beta_{2} * \mathrm{~d}_{0,3}{ }^{2}+\varepsilon$ \\
4 & Spurr & $\mathrm{PCT}=\beta_{0}+\beta_{1} * \mathrm{~d}_{0,3}{ }^{2} \mathrm{~h}+\varepsilon$ \\
5 & Stoate & $\mathrm{PCT}=\beta_{0}+\beta_{1} * \mathrm{~d}_{0,3}{ }^{2}+\beta_{2} * \mathrm{~d}_{0,3}{ }^{2} \mathrm{~h}+\beta_{3} * \mathrm{~h}+\varepsilon$ \\
6 & Meyer & $\mathrm{PCT}=\beta_{0}+\beta_{1} * \mathrm{~d}_{0,3}{ }^{2}+\beta_{2} * \mathrm{~d}_{0,3} \mathrm{~h}+\beta_{3} * \mathrm{~d}_{0,3}{ }^{2} \mathrm{~h}+\varepsilon$ \\
Logarithmic & & \\
7 & Husch & $\operatorname{In}(\mathrm{PCT})=\beta_{0}+\beta_{1} * \operatorname{In} \mathrm{d}_{0,3}+\operatorname{In}(\varepsilon)$ \\
8 & Schumacher-Hall & $\operatorname{In}(\mathrm{PCT})=\beta_{0}+\beta_{1} * \operatorname{In} \mathrm{d}_{0,3}+\beta_{2} * \operatorname{In} \mathrm{h}+\operatorname{In}(\varepsilon)$ \\
Modelling & & \\
9 & Stepwise & Stepwise
\end{tabular}

In which: $\mathrm{TCW}=$ Total carbon weight $(\mathrm{kg}) ; \mathrm{d}_{0,3}=$ diameter at $0,3 \mathrm{~m}$ above ground; $\mathrm{h}=$ total height $(\mathrm{m}) ; \beta_{0}, \beta_{1}, \beta_{3}, \beta_{3}=$ estimated regression coefficients. 
of residues. The logarithmic models were corrected in terms of logarithmic discrepancy by Meyer Correction Factor ( $\mathrm{Fc}$ ), before recalculation of Syx into kilograms (kg).

The selected equation was assessed in terms of presupposed residuals of homogeneous variance with White test, normality of residuals was assessed with Cramér-von Mises test, and residuals independence was assessed with Durbin-Watson test.

Fit statistics and modelling of total carbon weight were processed in the Statistical Analysis System SAS V. 9.1 (SAS Intitute Inc., 2004).

\section{RESULTS}

\subsection{Carbon contents}

Carbon contents of the components and total carbon contents are found in the Box-plot graph in Figure 1. Carbon contents found in total dry biomass was $46.7 \%$. When assessed between compartments, carbon contents in branches was $48.3 \%$, followed by aciculas (46.9\%), roots $(46.5 \%)$, and stems $(45.1 \%)$.

\subsection{Equation selection}

Adjusted equations to estimate dry weight of total carbon showed $\mathrm{R}^{2}$ aj. between 0.76 and 0.93 , and $\mathrm{Syx} \%$ from $18.5 \%$ to $22.9 \%$ according to Table 2 .

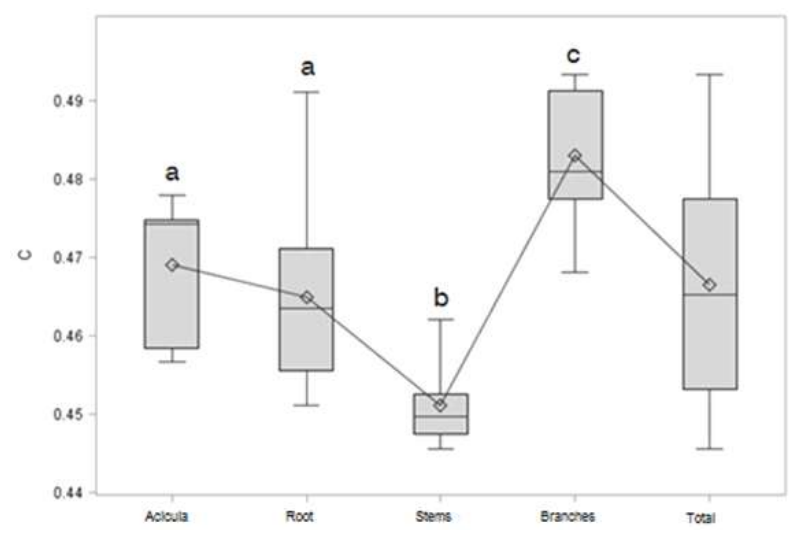

Figure 1 - Statistical summary of organic carbon contents by compartments of individuals in natural regeneration of Pinus taeda.

Figura 1 - Resumo estatístico dos teores de carbono por compartimentos dos indivíduos de regeneração natural de Pinus taeda.
Modelling performed with the Stepwise procedure (equation 9) showed the best statistics regarding fit and precision criteria $\left(\mathrm{R}^{2} \mathrm{aj} .=0.931 ; \mathrm{Syx} \%=18.5\right.$, respectively), with the inclusion of the independent variables diameter at $0.3 \mathrm{~m}$ above ground level and total height, transformed and combined.

The regression steps evidenced the inclusion of the independent variables $\operatorname{In}\left(\mathrm{d}^{2}{ }_{0,3} \mathrm{~h}\right)$ with the highest partial correlation $\mathrm{R}^{2}$ Partial $=92.7 \%$, followed by the variable $\mathrm{d}_{0,3}^{2}$ with $\mathrm{R}^{2}$ Partial $=0.57 \%$.

The analysis of variance and estimated parameters of regression modelling for total carbon weight is shown in Table 3. All adjusted coefficients were significant at $\alpha=5 \%$.

Thus, the final adjusted equation was:

$\operatorname{In}\left(\mathrm{PCT}_{\mathrm{i}}\right)=-3,90891-0,02227\left(\mathrm{~d}_{0,3}^{2}\right)_{\mathrm{i}}+0,91304$ $\operatorname{In}\left(\mathrm{d}_{0,3}^{2} \mathrm{~h}\right)_{\mathrm{i}}$

The residual dispersion according to the estimated dependent variable (Figure 2) has shown homogeneous distribution, without systematic errors that overestimated or underestimated values. The same behaviour may be evidenced by the dispersion of values observed in comparison with estimated values.

Model residues were homoscedastic with White test (Prob. $>\mathrm{x}^{2}=0.0832$ ), and showed normal distribution by Cramér-von Mises test (Prob. W-Sq = 0.2450). Furthermore, Durbin-Watson test showed no evidences of correlation between negative and positive errors (Prob. $<\mathrm{DW}=0.1756$ and Prob. $>\mathrm{DW}=0.8244$, respectively).

\section{DISCUSSION}

\subsection{Carbon contents}

Branches showed greater contents of carbon (48.3\%) with a significant difference between Tukey-Kramer test and the other tests. Through the same test, the average between aciculas (46.9\%) and roots (46.5\%) did not differ from each other. Stems, however, showed the smallest carbon contents (45.1\%), differing from the other compartments, and had the smallest variability in carbon contents (Figure 1). Thus, it is important to highlight that concentrations of carbon in compartments decreased from branches to aciculas, roots, and stems. 
Table 2 - Statistical adjustment for estimation of total carbon weight of individuals in natural regeneration of Pinus taeda. Tabela 2 - Estatística de ajuste para estimar o peso de carbono total das árvores de regeneração natural de Pinus taeda.

\begin{tabular}{cccccccc}
\hline Equation & $\beta_{0}$ & $\beta_{1}$ & $\beta_{2}$ & $\beta_{3}$ & $\mathrm{R}^{2} \mathrm{aj}$. & $\mathrm{Syx} \%$ & $\mathrm{Fc}$ \\
\hline 1 & $-0,42635$ & 0,30903 & - & - & 0,768 & 22,6 & - \\
2 & $-0,00549 \mathrm{~ns}$ & 0,04802 & - & - & 0,783 & 21,8 & - \\
3 & $-0,14122 \mathrm{~ns}$ & $0,09657 \mathrm{~ns}$ & 0,03351 & - & 0,784 & 21,8 & - \\
4 & 0,12821 & 0,00681 & - & - & 0,791 & 21,4 & - \\
5 & $-0,19138$ & $0,01561 \mathrm{~ns}$ & $0,00216 \mathrm{~ns}$ & 0,10489 & 0,833 & 19,4 & - \\
6 & $-0,07838$ & 0,00082364 & $0,04961 \mathrm{~ns}$ & $-0,00189$ & 0,834 & 18,8 & - \\
7 & $-3,36678$ & 2,22811 & - & - & 0,898 & 22,9 & 1,0524 \\
8 & $-3,77574$ & 1,49053 & 0,89559 & - & 0,926 & 20,7 & 1,0378 \\
9 & $-3,90891$ & $-0,02227$ & 0,91304 & - & 0,931 & 18,5 & 1,0349 \\
\hline
\end{tabular}

Table 3 - Analysis of variance and estimated parameters of total carbon weight model of individuals in natural regeneration of Pinus taeda.

Tabela 3 - Análise de variância e parâmetros estimados do modelo de peso do carbono total das árvores de regeneração natural de Pinus taeda.

\begin{tabular}{cccccc}
\hline VS & DF & SS & MS & F & Pr. $>$ F \\
\hline Model & 2 & 88,4853 & 44,2426 & 644,20 & $<0,0001$ \\
Error & 93 & 6,3870 & 0,0686 & - & - \\
Total & 95 & 94,8723 & - & - & - \\
\hline Variable & Coefficients & Standard Error & T value & $<0,0001$ \\
\hline Intercept & $-3,90891$ & 0,09447 & $-41,38$ & $<0,0060$ \\
$\mathrm{~d}^{2}$ & $-0,02227$ & 0,00792 & $-2,81$ & $<0,0001$ \\
$\left.\operatorname{In}_{\left(\mathrm{d}^{2}\right.}{ }_{0,3} \mathrm{~h}\right)$ & 0,91304 & 0,04851 & 18,82 & \\
\hline
\end{tabular}

In which: $\mathrm{VS}=$ variation source; $\mathrm{DF}=$ degrees of freedom; $\mathrm{SS}=$ sum of squares; $\mathrm{MS}=$ mean square; $\mathrm{F}=\mathrm{F}$ value; Pr. $>\mathrm{F}=$ probability of significance of $\mathrm{F}$ value.
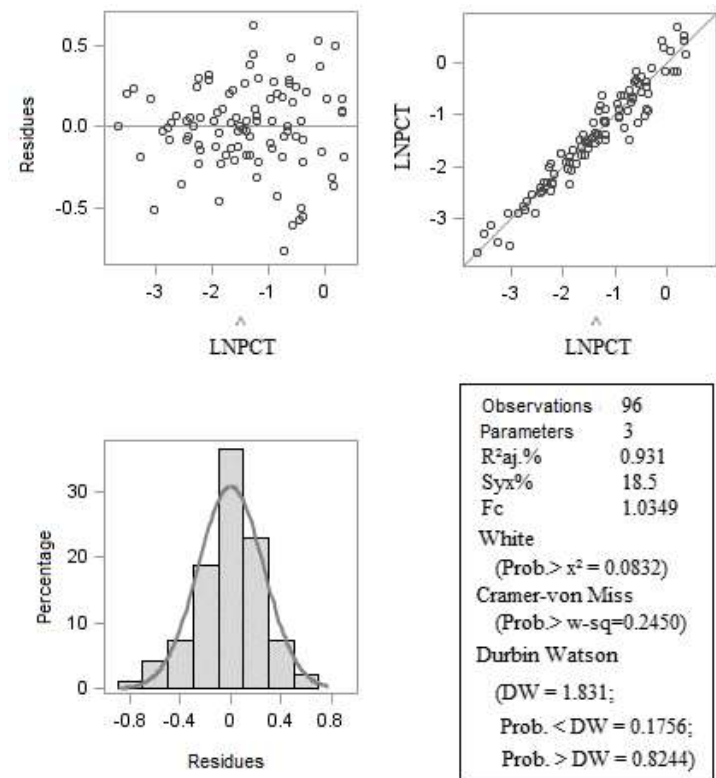

\begin{tabular}{|ll|}
\hline Observations & 96 \\
Parameters & 3 \\
$\mathrm{R}^{2}$ aj. $\%$ & 0.931 \\
Syx $\%$ & 18.5 \\
Fc & 1.0349 \\
White & \\
(Prob $>\mathrm{x}^{2}=0.0832$ ) \\
Cramer-von Miss \\
(Prob $>$ w-sq=0.2450) \\
Durbin Watson \\
(DW $=1.831 ;$ \\
Prob. $<\mathrm{DW}=0.1756 ;$ \\
Prob. $>\mathrm{DW}=0.8244$ )
\end{tabular}

Figure 2 - Residual analysis for the adjusted total carbon weight equation of individuals in natural regeneration of Pinus taeda.

Figura 2 - Análise dos resíduos da equação ajustada do peso de carbono total das árvores de regeneração natural de Pinus taeda.
The highest carbon contents in branches have also been reported in a study performed by $\mathrm{Fu}$ et al. (2013) in individuals of Larix olgensis, and by Li et al. (2011) and Tolunay (2009) in Pinus sylvestris individuals. However, Watzlawick et al. (2004) concluded that populations of Pinus taeda at 21 and 23 years old had the highest production of carbon in the wood of stems, followed by live branches, roots, dead branches, and aciculas.

In populations of Pinus taeda, Watzlawick et al. (2013) assume that stems have a major contribution in carbon contents. These results may be linked to several factors, as Li et al. (2011) report that carbon concentrations of trees of the same species may be affected by age, origin, and edaphloclimatic conditions. Other authors, however, describe that trees with the same diameter may have different carbon contents, since they show variation in height and stem shape, and also by being located in several sites and strata in forests (SOARES; OLIVEIRA 2002).

It is important to highlight that studies about carbon concentration for young trees of Pinus taeda settled in forest understories are still scarce and any comparison

Revista Árvore, Viçosa-MG, v.40, n.4, p.661-668, 2016 
of results demands more information regarding factors that might influence the detected differences such as light availability, genetic material, technique used for carbon analysis, and levels of competition.

Sette Junior et al. (2006) assessed organic carbon capture in populations of Pinus taeda and concluded that contents of carbon in young populations are higher in the upper third of trees; as they age, higher carbon contents concentrate in the medium third, and when trees reach maturity, populations show higher carbon contents in the lower third.

All in all, the results obtained in this study indicate that the use of a constant value to estimate carbon may lead to estimation errors, mainly when components are considered separately. Some researchers convert the amount of dry biomass into carbon, using a conversion factor of 0.5 , and acknowledge this value as an acceptable average (FONSECA et al., 2011a). However, if this conversion factor for estimation of total carbon had been adopted in this study we would have overestimated values of $3.3 \%$ (Figure 1), but overestimations increase as components are considered separately, as in this case: aciculas $(6 \%)$, roots $(7 \%)$, and stems (10\%). These observations corroborate the study developed by Fonseca et al. (2011 b), with errors from 4 to $6 \%$ in estimation of carbon, concluding that overestimations are still more common when considering less lignified compartments such as branches and leaves. Thus, the assumption that all plant biomass has a fraction of constant carbon increases errors of carbon estimation.

\subsection{Selection of equation}

The traditional equations tested to estimate total carbon weight showed lower precision adjustments in relation to the model developed with the Stepwise procedure (equation 9).

In other types of vegetation, Stepwise models have also shown better adjustments and equation precision for the estimation of total organic carbon, as in the study by Miranda et al. (2011) for restoration reforestations, and Souza et al. (2013) for native Bracatinga forests. These authors concluded that despite being efficient, the selected traditional equations seemed less accurate than the equations adjusted by Stepwise, reinforcing the importance of this method and the improvement it represents for modelling studies.

Revista Árvore, Viçosa-MG, v.40, n.4, p.661-668, 2016
In the current study, equation 9 has shown the best statistics regarding fit and precision criteria $\left(\mathrm{R}^{2} \mathrm{aj}\right.$.; Syx\%), with the inclusion of independent variables diameter at $0.3 \mathrm{~m}$ above ground and total height, converted and combined, which resulted in simplified models which are advantageous due to their field applicability and easiness to measure these variables (SEGURA; ANDRADE, 2008; CORREIA et al., 2010).

Despite the height being a difficult variable to measure in some species, likely to result in several errors, it can be estimated in populations through regression, i.e. h/d relationship. As for natural regeneration of small-sized individuals, these measures could be directly obtained from the tree, with higher accuracy.

Variables associated to crown dimensions were not significant with the Stepwise procedure due to their large variability within the forest population. This variability, however, is certainly caused by the conditions individuals are, which, in this case, refer mainly to the low incidence of light.

The model developed via Stepwise was efficient, with good fit and precision with no tendency to systematic errors. In addition, it is an easily applicable model according to the independent variables selected (diameter at $0.3 \mathrm{~m}$ above ground and height), corroborating studies developed by other authors (SOARES; OLIVEIRA, 2002; URBANO et al., 2008; SOUZA et al., 2013).

\section{CONCLUSION}

In general, carbon contents were not uniform among the assessed compartments. Carbon contents found in dry biomass of branches is significantly higher when compared to stems, aciculas, and roots. However, stems showed a significant lower carbon level in relation to other compartments.

The use of the commonly applied conversion factor of 0.5 may result in overestimations, especially when compartments are separately considered, as in this case, where overestimations reached $10 \%$ as evidenced for stems.

The traditional equations tested were less efficient, however, the equation adjusted by Stepwise showed better fit and precision according to the adopted statistical criteria, whose independent variables were 
diameter at $0.3 \mathrm{~m}$ above ground level and height, converted and combined.

In studies with pine trees, the ones that usually include biomass and carbon are conducted in planted forests. However, results obtained in the current work showed expressive values of carbon in the biomass of these plants, as expected, clearly indicating that they can work as an important complement in the real quantification of organic carbon in forest populations. This reinforces the importance of new studies directed to the natural regeneration of Pine trees.

\section{REFERENCES}

AMARO, M.A. Estoque volumétrico, de biomassa e de carbono em uma Floresta Estacional Semidecidual em Viçosa, Minas Gerais. Revista Árvore, v.37, n.5, p.849-857, 2013.

BALBINOT, R.; VALÉRIO, A. F.; SANQUETTA, C. R. Estoque de carbono em plantações de Pinus spp. em diferentes idades no Sul do estado do Paraná. Floresta, v.38, n.2, p.317-324, 2008

CORREIA, A. C., TOMÉ, M.; PACHECO, C. A.; FAIAS, S.; DIAS, A. C.; FREIRE, J.; CARVALHO, P. O.; PEREIRA, J. S. Biomass allometry and carbono factors for a Mediterranean (Pinus pinea L.) in Portugal. Instituto Nacional de Investigación y Tecnologia Agraria y Alimentaria, v. 19, n.3, p.418433,2010

FELDPAUSCH, T. R.; BANIN L.; PHILLIPS O. L.; BAKER T. R.; LEWIS S. L.; QUESADA C. A.; AFFUM-BAFFOE K.; ARETS E. J. M. M.; BERRY N. J.; BIRD M.; BRONDIZIO E. S.; CAMARGO P. DE.; CHAVE, J.; DJAGBLETEY, G.; DOMINGUES T. F.; DRESCHER M.; FEARNSIDE P. M.; FRANCA M. B.; FYLLAS N. M.; LOPEZGONZALEZ G.; HLADIK A.; HIGUCHI N.; HUNTER, M. O.; IIDA, Y. SALIM, K. A.; KASSIM A. R.; KELLER M.; KEMP, J.; KING, D. A.; LOVETT, J. C.; MARIMON, B. S.; MARIMONJUNIOR B. H.; LENZA, E.; MARSHALL, A. R.; METCALFE, D. J.; MITCHARD, E. T. A.; MORAN, E. F.; NELSON, B.W.; NILUS, R.; NOGUEIRA, E. M.; PALACE, M.; S. PATIÑO, S.; PEH K. S.-H.; RAVENTOS M. T.; REITSMA, J. M; SAIZ, G.; F. SCHRODT, F.; SONKÉ, B.; TAEDOUMG, H. E.; TAN, S.; WHITE, J.; WOLL, H.; LLOYD, J. Height-diameter allometry of tropical forest trees. Biogeosciences, v.8, p. 1081-1106, 2011.
FONSECA, W.; BENAYAS, J.M.R.; FEDERICO, E.A. Carbon accumulation in the biomass and soil of different aged secondary forests in the humid tropics of Costa Rica. Forest Ecology and Management, v.262, n.8, p.1400-1408, 2011a.

FONSECA, W.; ALICE, F.E.; BENAYAS, J.M.R. Carbon accumulation in aboveground and belowground biomass and soil of different age native forest plantations in the humid tropical lowlands of Costa Rica. International Journal on the Biology, Biotechnology, and Management of Afforestation and Reforestation, v.43, n.2, p.197-211, 2011 b.

FU, Y.; WANG, X.; SUN, Y. Carbon Concentration Variability of Larix olgensis in North-Eastern China. Advance Journal of Food Science and Technology, v.5, n.5, p.627-632, 2013.

ILYAS, S. Allometric Equation and Carbon Sequestration of Acacia mangium Willd. in Coal Mining Reclamation Areas. Civil and Environmental Research, v.3, n.1, p.2222-2863, 2013.

LI, X.; YI, M. J.; SON, Y.; PARK, P. S.; LEE, K, H.; SON, Y, M.; KIM, R. H.; JEONG, M. J. Biomass and carbon storage in an age-sequence of Korean Pine (Pinus koraiensis) plantation forests in Central Korea. Journal of Plant Biology, v.42, p.33-54, 2011.

MAKUNGWA, S.; CHITTOCK, A.; SKOLE, D. L.; KANYAMA-PHIRI, G. H.; WOODHOUSE, I. H. Allometry for Biomass Estimation in Jatropha Trees Planted as Boundary Hedge in Farmers' Fields. Forests, v.4, n.2, p.218-233, 2013.

MELLO, A. A.; SANQUETTA, C. R.; EISFELD, R. L.; NAKAJIMA. Quantidade de carbono remanescente e retirado em povoamento de Pinus taeda no sul do Paraná. Revista Acadêmica: Ciências Agrárias e Ambientais, v.8, n.2, p.123-130, 2010.

MIRANDA, D.L.C.; MELO, A.C.G.; SANQUETTA, C.R. Equações alométricas para estimativa de biomassa e carbono em árvores de reflorestamentos de restauração. Revista Árvore, v.3, n.3, p.679-689, 2011.

RAGLAND, K.W.; AERTS, D.J. Properties of wood for combustion analysis. Bioresource Technology, v.37, n.2, p.161-168, 1991.

RIBEIRO, S. C.; JACOVINE, L. A. G.; SOARES, C. P. B.; MARTINS, S. V.; SOUZA, A. L.; NARDELLI, A.

Revista Árvore, Viçosa-MG, v.40, n.4, p.661-668, 2016 
M. B. Quantificação de biomassa e estimativa de estoque de carbono em uma Floresta Madura no município de Viçosa, Minas Gerais. Revista Árvore, v.33, n.5, p.917926, 2009.

RITSON, P.; SOCHACKI, S. Measurement and prediction of biomass and carbon content of Pinus pinaster trees in farm forestry plantations, south-western Australia. Forest Ecology and Management, v. 175, n.13, p.103-117, 2003.

SAS Institute. The SAS System for Windows. Cary: 2004.

SANQUETTA, C. R. Métodos de Determinação de Biomassa Florestal. In: SANQUETTA, C.R. As florestas e o carbono. Curitiba: UFPR, 2002. p.119-69, 2002.

SEGURA, M.; ANDRADE, H.J. ¿Cómo construir modelos alométricos de volumen, biomasa o carbono de espécies leñosas perennes? Agroforestería de las Américas, n.46, p.89-96, 2008.

SETTE JUNIOR, C.R.; NAKAJIMA, N.Y.; GEROMINI, M.P. Captura de carbono orgânico em povoamentos de Pinus taeda 1 . na região de Rio Negrinho, SC. Floresta v.36, n.1, p.33-44, 2006.

SOARES, C.P.B.; OLIVEIRA, M.L.R. Equações para estimar a quantidade de carbono na parte aérea de árvores de eucalipto em Viçosa, Minas gerais. Revista Árvore, v.26, n.5, p.533-539, 2002.

SOCHA, J.; WEZYK, P. Allometric equations for estimating the foliage biomass of Scots pine. European Journal of Forest Research, v.126, p.263-270, 2007.

SOUZA, R. F.; MACHADO, S. A.; FIGUEIREDO FILHO, A.; KOEHLER, H. S. Modelagem do carbono orgânico total e da lenha por unidade de área para bracatingais nativos. Ciência Florestal, v.23, n.1, p.117$127,2013$.

TEDESCO, M. J.; GIANELLO, C.; BISSANI, C.A.; BOHNEN, H.; VOLKWEISS, S.J. Análises de solo, plantas e outros materiais. Departamento de solos, UFRGS, 174 p, 1995. (Boletim técnico, 5)

TOLUNAY, D. Carbon concentrations of tree components, forest floor and under storey in young
Pinus sylvestris stands in north-western Turkey. Journal of Forest Research, v.24, p.394-402, 2009.

TORRES, C.M.M.E.; JACOVINE, L.A.G.; SOARES, C.P.B.; OLIVEIRA NETO, S.N.; SANTOS, R.D.; CASTRO NETO, F. Quantificação de biomassa e estocagem de carbono em uma Floresta Estacional Semidecidual, no Parque Tecnológico de Viçosa, MG. Revista Árvore, v.37, n.4, p.647-655, 2013.

URBANO, E.; MACHADO, D. A.; FIGUEIREDO FILHO, A.; KOEHLER, H. S. Equações para estimar o peso de carbono fixado em árvores de Mimosa scabrella Bentham (Bracatinga) em povoamentos nativos. Cerne, v. 14, n.3, p.194-203, 2008.

WATZLAWICK, L. F.; CALDEIRA, M. V. W.; GODINHO, T. O.; BALBINOT, R.;

TRAUTENMULLER, J. W. Aboveground stock of biomass and organic carbon in stands of Pinus taeda L. Cerne, v.19, n.3, p.509-515, 2013.

WATZLAWICK, L. F.; CALDEIRA, M. V. W. VIERA, M.; SCHUMACHER, M. V.; GODINHO, T. O.; BALBINOT, R. Estoque de biomassa e carbono na Floresta Ombrófila Mista Montana Paraná. Scientia Forestalis, v.40, n.95, p.353-362, 2012.

WATZLAWICK, L. F.; EBLING, A. A.; RODRIGUES, A. L.; VERES, Q. J. I.; LIMA, A. M. Variação nos teores de carbono orgânico em espécies arbóreas da Floresta Ombrófila Mista. Floresta e Ambiente, v. 18, n. 3, p.248-258, 2011.

WATZLAWICK, L.F.; KOEHLER, H.S.; KIRCHNER, F.F. Estimativa de biomassa e carbono em plantios de Pinus taeda L. utilizando imagens do satélite IKONOS II. Ciência e Natura, v.28, n.1, p.45-60, 2006.

WATZLAWICK, L.F.; CALDEIRA, M.V.W. Estimativa de biomassa e carbono em povoamentos de Pinus taeda com diferentes idades. Biomassa e Energia, v.1, p.371-380, 2004.

WINK, C.; MONTEIRO, J. S.; REINERT, D. J.; LIBERALESSO, E. Parâmetros da copa e a sua relação com o diâmetro e altura das árvores de eucalipto em diferentes idades. Scientia Forestalis, v.40, n.93, p.57-67, 2012. 